\title{
PENGARUH KEBIJAKAN DIVIDEN DAN UKURAN PERUSAHAAN TERHADAP LEVERAGE PERUSAHAAN DENGAN INVESTMENT OPPORTUNITY SET (IOS) SEBAGAI VARIABEL MODERASI PADA SEKTOR TRADES, SERVICES \& INVESTMENT YANG TERDAFTAR DI BEI
}

\author{
Yakobus Novritwo Sigalingging ${ }^{1)}$, Aminar Sutra Dewi ${ }^{2)}$ \\ ${ }^{1,2)}$ Sekolah Tinggi Ilmu Ekonomi KBP \\ Email $^{1)}$ : sigalinggingyackobus123@gmail.com \\ Email $^{2)}$ aminarsutradewi@akbpstie.ac.id
}

\begin{abstract}
This study aims to test empirically analysis of the effect of dividend policy and firm size on corporate leverage with investment opportunity set as a moderation variable. Hypothesis testing in this study using Moderated Regression Analysis (MRA). The sample is done by using purposive sampling method. The data used are secondary data in the form of financial statement data from the retail industry sub-sector (retail trade) from 2014-2016. Statistical methods used multiple linear regression analysis using Moderated Regression Analysis (MRA) testing, classical assumption and hypothesis. The results of this study indicate that dividend policy has a negative and insignificant effect on leverage, firm size has a positive and significant impact on corporate leverage. While using Moderated Regression Analysis (MRA) indicates that Investment Opportunity Set (IOS) does not affect the relationship between dividend policy and corporate leverage and Investment Opportunity Set (IOS) also does not affect the relationship between company size and company leverage.
\end{abstract}

Keywords: Dividend Policy, Company Size, Investment Opportunity Set (IOS) and Corporate Leverage.

\begin{abstract}
ABSTRAK
Penelitian ini bertujuan untuk menguji secara empiris analisis pengaruh kebijakan dividen dan ukuran perusahaan terhadap leverage perusahaan dengan investment opportunity set sebagai variabel moderasi. Pengujian hipotesis dalam penelitian ini menggunakan Moderated Regression Analysis (MRA). Sampel dilakukan dengan menggunakan metode purposive sampling. Data yang digunakan adalah data sekunder berupa data laporan keuangan dari sub sektor industri ritel (retail trade) dari tahun 2014-2016. Metode statistik menggunakan analisis regresi linear berganda dengan menggunakan pengujian Moderated Regression Analysis (MRA), asumsi klasik dan hipotesis. Hasil penelitian ini menunjukkan bahwa kebijakan dividen berpengaruh negatif dan tidak signifikan terhadap leverage, ukuran perusahaan berpengaruh positif dan signifikan terhadap leverage perusahaan. Sementara dengan menggunakan Moderated Regression Analysis (MRA) menunjukkan bahwa Investment Opportunity Set (IOS) tidak mempengaruhi hubungan antara kebijakan dividen dengan leverage perusahaan dan Investment Opportunity Set (IOS) juga tidak mempengaruihi hubungan antara ukuran perusahaan dengan leverage perusahaan.
\end{abstract}




\section{A. PENDAHULUAN}

Industri manufaktur memiliki peranan yang begitu penting dalam sistem perekonomian Indonesia. Perkembangan industri manufaktur saat ini telah menciptakan suatu persaingan yang tajam antar perusahaan industri manufaktur. Situasi perkembangan ekonomi yang meningkat mendorong manajemen perusahaan agar dapat bekerja lebih efektif dan efisien agar dapat mempertahankan kestabilan perusahaan serta menjaga kelangsungan hidup pada persaingan perekonomian bisnis yang begitu ketat terutama pada perusahaan go publik di pasar modal (Astuti \& Efni, 2015).

Leverage adalah suatu kemampuan yang dimiliki perusahaan dalam memenuhi likuiditas jangka pendek dan likuiditas jangka panjang atau bisa diukur dengan sejauh mana perusahaan didanai oleh sumber eksternal perusahaan yaitu hutang. Tujuan perusahaan dalam penggunaan Leverage yaitu supaya keuntungan yang didapat melebihi biaya aset dan sumber dana lainnya, oleh sebab itu akan meningkatkan dividen. (Novari \& Lestari, 2016).

Ketersediaan dana yang cukup untuk membiayai aktivitas operasional merupakan salah satu faktor yang penting bagi perusahaan, dikarenakan persaingan industri yang semakin ketat akan menjadi faktor penghambat keberlangsungan hidup sebuah perusahaan serta peluang untuk berkembang bagi perusahaan tersebut. Pendanaan tersebut bisa didapat dari internal dan eksternal perusahaan. Pendanaan internal bersumber dari pihak internal perusahaan itu sendiri yang disetor ataupun laba ditahan dan tidak dibagikan kepada investor atau pemegang saham sebagai dividen, sedangkan pendanaan eksternal bersumber dari hutang yang didapat dari pihak kreditur (Masruroh, Nursanti, \& Lisa, 2011).

Pada tahun 2017 terjadi penurunan minat beli masyarakat, dapat dilihat dari menurunnya tingkat pertumbuhan sub sektor bisnis yaitu perusahaan ritel. Pada sektor ritel pertumbuhannya minus, anjloknya penjualan ritel telah terjadi 2.5 tahun yang lalu, kondisi perusahaan ritel (retail) di saat ini sudah 2,5 tahun underperformance, yang membuat situasi perusahaan ritel di Indonesia dalam situasi atau kondisi tidak meyakinkan. Adapun dampak yang akan terjadi dalam perusahaan ritel (retail trade) jika daya beli turun secara terus menerus maka industri ritel akan mengalami penurunan tingkat penjualan, yang mana data yang tercatat pada BAPPENAS menunjukan bahwa pertumbuhan penjualan ritel riil dari 16,3 persen pada Juni 2016, anjlok menjadi 6,7 persen di Juni 2017. Semantara hutang yang dipergunakan dalam kegiatan operaional perusahaan terus bertambah. Dengan ini kesulitan perusahaan dalam 
melunasi hutang-hutangnya akan terjadi adapun dampak lainnya maka minat investor akan berkurang. (Liputan6, 2017)

Pada dasarnya perusahaan juga melaksanakan aktivitas operasionalnya yang tak terlepas dari kewajiban dalam membayar dividen guna memberikan balas jasa kepada investor. Kebijakan dividen adalah keputusan dalam menentukan berapa besar bagian dari pendapatan yang diperoleh perusahaan yang akan diberikan kepada para pemegang saham yang diinvestasikan atau ditahan di dalam perusahaan (Larasati, 2011). Dividen dibayarkan juga untuk memberikan suatu sinyal kepada pemegang saham dimana dana yang ditanamkan di perusahaan terus berkembang.

Ukuran perusahaan dapat berpengaruh terhadap mudahnya perusahaan untuk memperoleh hutang. Perusahaan besar memiliki total aktiva yang dominan lebih besar dan dapat dijaminkan dalam sumber pendanaan. Hal ini memungkinkan bahwa ukuran perusahaan berpengaruh terhadap akses perusahaan untuk memperoleh sejumlah dana. Kebijakan hutang dapat digunakan untuk mencapai nilai perusahaan yang diinginkan, tetapi kebijakan hutang tergantung dari ukuran perusahaan. Hal ini menunjukkan bahwa sebuah perusahaan yang besar relative akan lebih mudah untuk mengakses ke pasar modal. Hal ini mengindikasikan bahwa perusahaan dengan aktiva besar akan relatif mudah memenuhi sumber dana dari hutang melalui pasar modal (Nuraina, 2012)

Purnami dan artini (2016) mengatakan bahwa Investment Opportunity Set (IOS) adalah suatukombinasi antara aktiva yang dimiliki dan pilihan-pilihan investasi dimasa yang akan datang dengan net present value positif. IOS dapat digunakan sebagai pilihan investasi saat ini dan diharapkan akan menghasilkan keuntungan yang lebih banyak di masa yang akan datang. Keuntungan yang dihasilkan dalam bentuk return. Bagi perusahaan yang tidak dapat menggunakan kesempatan investasi tersebut akan mengalami suatu pengeluaran yang lebih tinggi dibandingkan dengan nilai kesempatan yang hilang (Astuti \& Efni, 2015).

Dalam penelitian yang dilakukan oleh Kennedy. R. Fitrios dan R. Fitri (2009) tentang Pengaruh Dividen, Aliran Kas Bebas, Ukuran Perusahaan, Profitabilitas dan Risiko Terhadap Leverage Perusahaan Dengan Investment Opportunity Set (IOS) Sebagai Variabel Moderating menemukan bahwa IOS tidak mempengaruhi hubungan antara kebijakan dividen dengan Leverage perusahaan. Hasil penelitian ini menunjukkan hal yang berbeda dari penelitian sebelumnya yang dilakukan oleh Masruroh, dkk (2011) tentang Analisis Pengaruh Moderating Investment Opportunity Set Dengan Kebijakan Dividend Serta Moderating Investment Opportunity Set Dengan Arus Kas Bebas Terhadap Tingkat Leverage Perusahaan bahwa IOS mempengaruhi hubungan antara kebijakan dividen dengan Leverage perusahaan dimana IOS mempengaruhi hubungan antara kebijakan dividen dengan Leverage perusahaan. 
Berdasarkan latar belakang di atas serta fenomena dari perbedaan hasil penelitian terdahulu, peneliti tertarik untuk menganalisis pengaruh dividen dan ukuran perusahaan terhadap leverage perusahaan dengan Investment Opportunity Set (IOS) sebagai variabel moderasi pada sektor trade, services \& investment yang terdafar di BEI.

\section{B. TINJAUAN PUSTAKA}

\section{Defenisi Leverage Perusahaan}

Moh. Syadeli (2013) mengatakan bahwa hutang (Leverage) merupakan salah satu cara untuk memperoleh dana dari pihak ekternal (kreditur). Kebijakan hutang merupakan kebijakan yang diambil oleh pihak manajemen dalam rangka memperoleh sumber pembiayaan bagi perusahaan sehingga dapat digunakan untuk membiayai aktivitas operasional perusahaan. Untuk memenuhi kebutuhan pendanaan, pemegang saham lebih menginginkan pendaan perusahaan yang dibiayai dengan hutang karena dengan penggunaan hutang hak mereka terhadap perusahaan tidak akan berkurang.

Dalam penelitian Nuraina (2012) mengemukakan bahwa Kemampuan perusahaan mengelola hutang merupakan salah satu penarik minat investor. Untuk memperoleh persepsi positif dari investor yang akhirnya dapat menaikkan harga saham, pihak manajemen akan menggunakan Leverage pada tingkatan yang optimal. Penggunaan Leverage yang semakin besar dalam struktur modal perusahaan akan menyebabkan biaya bunga semakin besar sehingga keuntungan per lembar saham yang menjadi hak pemegang saham akan semakin besar pula.

\section{Defenisi Kebijakan Dividen}

Dividen pada dasarnya merupakan bagian dari keuntungan perusahaan yang akan dibagikan kepada pemilik perusahaan atau investor. Kebijakan dividen adalah kebijakan yang menyangkut masalah pembagian laba yang menjadi hak pemegang saham (Nabela, 2012). Kebijakan dividen adalah penentuan pembagian pendapatan antara pembagian dividen untuk pemegang saham dan untuk reinvestasi dalam perusahaan (Masruroh et al.. 2011). Pemegang saham mempunyai hak untuk menjual saham setiap saat sehingga perputaran jual-beli saham sangat cepat dan berubah-rubah. Oleh karena komposisi pemegang saham berubah-rubah maka menentukan siapa yang berhak atas dividen menjadi sulit, sehingga diperlukan prosedur untuk mengatur pembayaran deviden.

Dalam penelitian yang dilakukan oleh Ade Pendria Astuti dan Yulia Efni (2015) mengatakan bahwa kebijakan dividen adalah keputusan mengenai berapa banyak laba saat ini yang akan dibayarkan sebagai dividen sebagai ganti dari investasi yang ditanamkan dan berapa banyak 
yang dipertahankan untuk investasi kembali didalam perusahaan. Sedangkan pada penelitian Yoandhika Nabela (2012) mengatakan bahwa kebijakan dividen merupakan suatu keputusan untuk menentukan berapa besar bagian dari pendapatan perusahaan yang akandiberikan kepada pemegang saham yang diinvestasikan kembali atau ditahan dalam perusahaan. Berdasarkan hal tersebut dapat dilihat bahwa jika perusahaan meningkatkan pembayaran dividennya maka dana yang tersedia untuk pendanaan (laba ditahan) akan semakin kecil.

\section{Defenisi Ukuran Perusahaan}

Ukuran perusahaan adalah suatu skala dimana dapat diklasifikasikan sebagai besar kecilnya perusahaan dengan berbagai cara antara lain dengan total aset perusahaan, log size, nilai pasar saham, dan lain-lain (Novari \& Lestari. 2016). Selain itu.ukuran perusahaan juga dapat digambarkan melalui total aktiva, jumlah penjualan.rata-rata penjualan aset dan rata-rata total aktiva perusahaan. Ukuran perusahaan turut menentukan tingkat kepercayaan investor.Semakin besar perusahaan, maka semakin dikenal oleh masyarakat yang artinya semakin mudah untuk mendapatkan informasi. Bahkan perusahaan besar yang memiliki total aktiva dengan nilai aktiva yang cukup besar dapat menarik investor untuk menanamkan modalnya pada perusahaan tersebut.

Moh.Syadeli (2013) dalam penelitiannya mengatakan bahwa Ukuran perusahaan merupakan karakteristik perusahaan yang dapat mengklasifikasikan apakah suatu perusahaan termasuk kedalam ukuran perusahaan kecil.menengah.ataupun besar. Perusahaan kecil sangat rentan terhadap perubahan kondisi ekonomi dan cenderung kurang menguntungkan sedangkan perusahaan besar dapat mengakses pasar modal dan dengan kemudahan tersebut maka dapat disimpulkan bahwa perusahaan memiliki fleksibilitas dan kemampuan untuk mendapatkan dana atau permodalan.

\section{Defenisi Investment Opportunity Set (IOS)}

Investment Opportunity Set (IOS) adalah beban yang dikeluarkan oleh pihak manajemen yang mencerminkan nilai perusahaan sesuai dengan kebijakan dari manajemen itu sendiri (Aristantia \& Putra. 2015).Investment Opportunity Set (IOS) juga dapat digunakan sebagai pilihan investasi saat ini dan diharapkan akan menghasilkan keuntungan yang lebih banyak di masa yang akan datang. Investment Opportunity Set (IOS) merupakan suatu kombinasi antara aktiva yang dimiliki dan pilihanpilihan investasi dimasa yang akan datang dengan net present value (Purnami \& Artini. 2016)

Apabila kondisi perusahaan sangat baik maka pihak manajemen akan cenderung lebih memilih investasi baru daripada membayar dividen yang tinggi. Dana yang seharusnya dapat dibayarkan sebagai dividen tunai kepada pemegang saham akan digunakan untuk pembelian investasi yang 
menguntungkan, bahkan untuk mengatasi masalah underinvestment. Sebaliknya, perusahaan yang mengalami pertumbuhan lambat cenderung membagikan dividen lebih tinggi untuk mengatasi masalah overinvestment (Suharli. 2007).

\section{Pengaruh Kebijakan Dividen Terhadap Leverage Perusahaan}

Keputusan pendanaan berkaitan dengan pemilihan sumber dana baik berasal dari internal perusahaan maupun eksternal perusahaan, akan sangat mempengaruhi perusahaan. Sumber dana yang berasal dari sumber internal perusahaan adalah laba ditahan sedangkan dana yang berasal dari eksternal perusahaan adalah dana yang berasal dari kreditur dan peserta atau pengambil bagian di dalam perusahaan. Apabila perusahaan memenuhi kebutuhan pendanaan dari penerbitan saham baru dikatakan perusahaan itu melakukan pendanaan atau pembelanjaan modal sendiri. Dalam melaksanakan fungsi pemenuhan kebutuhan dana dan fungsi pendanaan, manajer keuangan selalu mencari alternatif-alternatif sumber dana untuk kemudian dianalisa untuk memutuskan langkah terbaik dalam pendanaan perusahaan. (Arieska \& Gunawan. 2009)

Dalam penelitian yang dilakukan oleh Susanto (2011) kebijakan dividen berpengaruh terhadap kebijakan hutang. Kebijakan dividen yang stabil menyebabkan adanya keharusan bagi perusahaan untuk menyediakan sejumlah dana guna membayar jumlah dividen yang ditetapkan tersebut. Hasil yang berbeda dilakukan oleh Djabid (2009) menemukan bahwa kebijakan dividen perpengaruh positif dan tidak signifikan terhadap kebijakan utang.

$\mathrm{H} 2$ = Diduga kebijakan dividen berpengaruh positif dan signifikan terhadap Leverage Perusahaan.

\section{Pengaruh Ukuran Perusahaan Terhadap Leverage Perusahaan}

Perusahaan besar ataupun kecil dapat terlihat melalui seberapa banyak perusahaan memiliki total aktiva. Perusahaan yang memiliki ukuran semakin besar akan membuat seorang investor menaruh perhatian yang besar pada perusahaan tersebut. Kondisi tersebut dapat terjadi karena perusahaan besar cenderung mempunyai kondisi yang semakin baik.Kondisi perusahaan yang baik dapat membuat investor ingin memiliki saham perusahaan sehingga dapat meningkatkan penawaran harga saham di pasaran. (Suwardika \& Mustanda. 2017)

Dalam penelitian yang dilakukan oleh Moh. Syadeli (2013) menemukan bahwa ukuran perusahaan berpengaruh terhadap Leverage perusahaanyang berarti semakin besar ukuran perusahaan, mengakibatkan peningkatan penggunaan hutang. Hasil yang sama juga ditemukan oleh Nuraina (2012) bahwa ukuran perusahaan juga berpengaruh terhadap Leverage perusahaan 
$\mathrm{H} 2$ = Diduga ukuran perusahaan berpengaruh positif dan signifikan terhadap Leverage perusahaan.

\section{Pengaruh Kebijakan Dividen Terhadap Leverage Perusahaan Dengan Investment Opportunity Set (IOS) Sebagai Variabel Moderasi}

Kebijakan dividen berkaitan dengan keputusan mengenai seberapa besar laba perusahaan akan dibagikan kepada pemegang saham atau menahannya untuk diinvestasikan kembali ke dalam perusahaan. Apabila dividen yang dibayarkan secara tunai semakin tinggi, maka dana yang tersedia untuk reinvestasi akan semakin rendah. Dividen ini selanjutnya dapat menyebabkan terjadinya perilaku pecking order yang mempengaruhi penggunaan laba ditahan. Teori pecking order menyatakan bahwa apabila internal equity yang ada di perusahaan tidak mencukupi untuk mengatasi jumlah kebutuhan dana, maka perusahaan akan menggunakan sumber dana eksternal mulai dari yang paling kecil risikonya, yaitu hutang.

Investment Opportunity Set (IOS) tinggi juga mencerminkan tingginya risiko yang harus ditanggung oleh lender sehingga menyebabkan cost of equity. Oleh karena itu tinggi rendahnya Investment Opportunity Set (IOS) dapat menentukan kuatnya hubungan antara dividen dengan Leverage prusahaan, karena Investment Opportunity Set (IOS) dapat mempengaruhi cost of debt bagi perusahaan dan kemakmuran perusahaan untuk akses kepenyediaan dana (Kennedy, Fitrios, \& Fitri, 2009)

Dari hasil penelitian yang dilakukan oleh Masruroh, dkk (2011) menemukan bahwa IOS mempengaruhi hubungan antara kebijakan dividen dengan Leverage perusahaan sedangkan Kennedy, Fitrios, \& Fitri (2009) menemukan hasil yang sama bahwa IOS juga tidak mempengaruhi hubungan antara kebijakan dividen dengan Leverage perusahaan.

$\mathrm{H} 3$ = Diduga kebijakan dividen berpengaruh positif dan signifikan terhadap Leverage perusahaan dengan Investment Opportunity Set (IOS) sebagai variabel moderasi.

\section{Pengaruh Ukuran Perusahaan Terhadap Leverage Perusahaan Dengan Investment Opportunity Set (IOS) Sebagai Variabel Moderasi}

Perusahaan besar dapat dengan mudah mengakses pasar modal karena perusahaan besar memiliki fleksibilitas dan kemampuan untuk mendapatkan sumber dana. Semakin besar perusahaan maka semakin banyak dana yang digunakan untuk menjalankan operasi perusahaan (Kennedy, Fitrios, \& Fitra, 2009). Perusahaan besar dapat dengan mudah mengakses ke pasar modal. Kemudahan untuk mengakses ke pasar modal berarti perusahaan memiliki fleksibilitas dan kemampuan untuk mendapatkan dana, karena kemudahan aksebilitas ke pasar modal dan kemapuannya untuk memunculkan dana lebih besar (Nuraina, 2012)

Dalam penelitian yang dilakukan Kennedy, dkk (2009) tentang PengaruhDividen, Aliran Kas Bebas, Ukuran Perusahaan, Profitabilitas 
Dan Risiko Terhadap Leverage Perusahaan Dengan Investment Opportunity Set (IOS) Sebagai Variabel Moderasi menemukan bahwa IOS tidak mempengaruhi hubungan antara Ukuran Perusahaan dengan Leverage perusahaan. Hasil yang sama juga ditemukan oleh Rofniati (2007) tentang Analisis Moderasi Investment Opportunity Set (IOS) Terhadap Hubungan Antara Dividen, Aliran Kas Bebas, Ukuran Perusahaan dan Profitabilitas Dengan Tingkat Leverage Perusahaan bahwa IOS tidak mempengaruhi hubungan antara Ukuran Perusahaan dengan Leverage perusahaan.

H4 = Diduga Ukuran Perusahaan berpengaruh positif dan tidak signifikan terhadap Leverage perusahaan dengan Investment Opportunity Set (IOS) sebagai variabel moderasi.

\section{METODE PENELITIAN}

\section{a. Jenis Penelitian}

Jenis penelitian dalam proposal yang saya ajukan ini adalah kuantitatif yaitu data yang berupa angka-angka (Novari, 2016). Data kuantitatif adalah data yang berbentuk angka atau data kualitatif yang diangkakan (Sugiyono, 2015). Data kuantitatif dalam penelitian ini digunakan dan dikembangkan dalam model matematis yang akan memunculkan hipotesis.

\section{b. Objek Penelitian}

Objek dalam penelitian ini adalah sektor Trade, Services dan Investment yang terdaftar di Bursa Efek Indonesia (BEI). Bursa Efek Indonesia merupakan tempat yang tepat dan akurat mengenai informasi perusahaan-perusahaan yang telah Go Public.

\section{c. Populasi dan Sampel}

Populasi adalah wilayah generalisasi yang terdiri atas objek atau subjek yang mempunyai kuantitas dan karakteristik tertentu yang diterapkan oleh peneliti untuk dipelajari dan kemudia ditarik kesimpulannya (Sugiyono, 2015). Populasi dalam penelitian ini adalah industri sub sektor ritel (retail trade) yang terdaftar di Bursa Efek Indonesia (BEI) pada tahun 2014-2016 sebanyak 23 perusahaan.

Sampel adalah bagian dari jumlah dan karakteristik yang dimiliki oleh populasi (Sugiyono, 2015). Sampel yang digunakan ditentukan dengan metode purposive sampling yaitu penentuan sampel dengan terlebih dahulu menentukan kriteria-kriteria yang diinginkan dari sampel (Larasati, 2011). Beberapa kriteria dalam pemilihan sampel adalah:

1. Perusahaan yang dipilih dalam bentuk sub sektor industri ritel (retail trade) yang tercatat di Bursa Efek Indonesia (BEI) selama tahun 2014-2016,

2. Tersedia data laporan keuangan selama kurun waktu penelitian periode berakhir 31 Desember. 
3. Perusahaan yang menyediakan data mengenai variabel-variabel yang digunakan dalam penelitian ini selama periode 2014-2016.

Jumlah sampel industri ritel (retail trade) yang memenuhi kriteria adalah sebanyak 15 perusahaan

\section{d. Jenis dan Sumber Data}

Penelitian ini menggunakan jenis data sekunder berupa data laporan keuangan dari sub sektor industri ritel (retail trade) yang dijadikan sebagai sampel selama periode tahun 2014-2016. Menurut Indriantoro (1999) dalam Kennedy, dkk (2009), data sekunder adalah penelitian arsip (archival research) yang memuatkejadian masa lalu (historis).Data bersumber dari website Bursa Efek Indonesia (BEI) www.idx.co.id.

\section{e. Teknik Pengumpulan Data}

Dalam penelitian ini, metode pengambilan data yang digunakan adalah dengan metode dokumentasi karena datanya berupa data sekunder. Metode dokumentasi adalah suatu metode yang mempelajari catatan-catatan maupun dokumen yang berbentuk laporan keuangan perusahaan yang telah diaudit.

\section{f. Teknik Analisis Data}

\section{Analisis Statistik Deskriptif}

Statistik deskiptif adalah statistik yang berfungsi untuk mendeskripsikan atau memberi gambaran terhadap objek yang diteliti melalui data sampel atau populasi sebgaimana adanya, tanpa melakukan analisis dan membuat kesimpulan yang berlaku untuk umum (Novari, 2016)

Dalam analisis statistik deskriptif akan digunakan untuk mendeskripsikan cara penyajian data melalui tabel biasa, tabel distribusi frekuensi, diagram lingkaran dan grafik gambar. Penjelasan kelompok melalui modus, median, mean, mediasi dan variasi kelompok melalui rentang dan simpangan baku.

\section{Uji Asumsi Klasik}

Ada tiga asumsi yang terpenting sebagai syarat penggunaan metode. Asumsi klasik tersebut adalah asumsi normalitas, Multikolinearitas, dan heterokedastisitas.

\section{Uji Normalitas}

Uji normalitas bertujuan untuk mengetahui apakah dalam model regresi, variable pengganggu atau residual memiliki distribusi normal (Masruroh, Nursanti, \& Lisa, 2011). Dasar pengambilan keputusan dalam pengujian ini yakni: jika nilai signifikan lebih besar dari nilai alpha (5\%) maka data tersebut dikatakan normal. Uji normalitas bertujuan untuk menguji apakah dalam model regresi, variabel residualnya mempunyai distribusi normal atau tidak normal (Purnami \& Artini, 2016). Apabila hasil uji normalitas dengan Kolmogorov- 
Smirnov, diketahui bahwa Alpha $(>0,05)$, sehingga dapat dikatakan bahwa data terdistribusi secara normal dan asumsi normalitas telah terpenuhi dan sebaliknya apabila aplha $(<0,05)$ maka data tidak terdistribusi secara normal.

\section{Uji Multikolinearitas}

Uji multikolinearitas adalah pengujian dari asumsi untuk membuktikan bahwa variabel-variabel bebas dalam suatu model tidak saling berkorelasi satu dengan yang lainnya. Adanya multikolinearitas dapat menyebabkan model regresi yang diperoleh tidak valid untuk menaksir variabel independen (Purnami \& Artini, 2016). Untuk mendeteksi ada atau tidaknya multikolinieritas di dalam model regresi dapat dilihat dari nilai tolerance dan variance inflation factor (VIF). Nilai cut-off yang umum dipakai untuk menunjukkan adanya multikolinieritas adalah nilai tolerance $>0,10$ atau sama dengan nilai VIF $<10$.

\section{Uji heteroskidastisitas}

Uji heteroskedastistas bertujuan menguji apakah dalam model regresiterjadi ketidaksamaan varian dari residual satu pengamatan kepengamatan lain. Model regresi yang baik adalah homokedastisitas, atau tidak terjadi heteroskedastisitas. (Purnami \& Artini, 2016). Untuk melihat ada atau tidaknya heteroskedastisitas dapat dilakukan dengan uji Glejser. Dalam uji ini apabila signifikasinya diatas tingkat kepercayaan $5 \%(0,05)$.

\section{g. Analisis Regresi dengan Variabel Moderasi}

Analisis regresi linear dengan variabel moderasi ini, digunakan untuk melihat hubungan antara sebuah variabel dependen (tidak bebas) dengan dua atau lebih variabel independen (bebas) pada tahap I (satu). Sedangkan pada tahap II (dua), analisis linear dengan variabel moderasi digunakan dalam melihat pengaruh moderasi dalam mempengaruhi hubungan antara variabel independen terhadap variabel dependen. Adapun persamaan dalam penelitian ini adalah :

1. Analisis Regresi Tahap I $\mathrm{Y}=\alpha+\beta_{1} \mathrm{X}_{1}+\beta_{2} \mathrm{X}_{2}+\mathrm{e}$

2. Analisis Regresi Tahap II

$$
\mathrm{Y}=\alpha+\beta_{1} \mathrm{X}_{1}+\beta_{2} \mathrm{X}_{2}+\beta_{3} \mathrm{X}_{1} * \mathrm{Z}+\beta_{4} \mathrm{X}_{2} * \mathrm{Z}+\mathrm{e}
$$

\section{h. Uji Hpotesis}

\section{Uji F (Uji Simultan)}

Uji F digunakan untuk mengetahui apakah independent variable (secara bersama-sama) berpengaruh secara signifikan atau tidak terhadap dependent variable. Bila signifikan berpengaruh berarti model yang diuji adalah model yang baik dipakai dalam penyederhanaan dunia nyata.(Masruroh et al., 2011) 


\section{Uji Parsial (Uji t)}

Uji T digunakan untuk mengetahui pengaruh independent variable secara individu terhadap dependent variable.(Masruroh et al., 2011). Pengujian dilakukan dengan menggunakan significance level 0,05 $(\alpha=5 \%)$. Dimana penerimaan dan penolakan hipotesis dilakukan dengan kriteria jika nilai signifikansi ( $\left.t_{\text {hitung }}>t_{\text {tabel }}\right)$ atau $\alpha<0,05$ maka hipotesis ditolak dan sebaliknya, jika signifikansi $\left(t_{\text {hitung }}<\right.$ $t_{\text {tabel }}$ ) atau $\alpha>0,05$ maka hipotesis ditolak.

\section{Uji R-Square (Koefisien Determinasi)}

Nilai Adjusted R-Square yang semakin mendekati 1 (satu) menunjukkan semakin kuat kemampuan variabel independen dalam menjelaskan variabel dependen. Apabila nilai Adjusted R-Square sama dengan 0 berarti variabel independen tidak berpengaruh terhadap variabel dependen (Nuraina, 2012)

\section{i. Defenisi Operasional Variabel}

Variabel-variabel yang dipergunakan dalam penelitian ini yaitu kebijakan dividen $\left(\mathrm{X}_{1}\right)$, ukuran perusahaan $\left(\mathrm{X}_{2}\right)$, Investment Opportunity Set (IOS) sebagai varabel moderasi (Z) dan variabel leverage perusahaan (Y). Selanjutnya dapat diuraikan definisi operasionalnya dari penelitian ini sebagai berikut:

\section{Kebijakan Dividen}

Variabel ini diukur dengan beberapa instrumen yang telah digunakan oeh (Hemastuti 2014) yaitu Dividend Payout Ratio (DPR) yang merupakan rasio antara dividen perlembar saham (DPS) dengan laba perlembar saham (EPS).

\section{Ukuran Perusahaan}

$$
D P R=\frac{D P S}{E P S}
$$

Variabel ini diukur dengan beberapa instrumen yang telah digunakan oleh (Novari \& Lestari. 2016) yaitu Size, dimana dilihat dari seberapa besar Logaritma natural total aset yang dimiliki oleh perusahaan.

$$
\text { Size }=L_{n} \text { Total Asset }
$$

\section{Investment Opportunity Set (IOS)}

Variabel ini diukur dengan beberapa instrumen yang telah digunakan oleh (Masruroh et al.. 2011) adalah Market to Book Value Of Equity (MVEBVE) yaitu:

$$
\text { MVEBVE }=\frac{\text { Lembar Saham Beredar } x \text { Harga Saham Penutupan }}{\text { Total ekuitas }}
$$

\section{Leverage Perusahaan}


Variabel ini diukur dengan beberapa instrumen yang telah digunakan oleh (Masruroh et al.. 2011) yaitu rasio antara hutang perusahaan dengan total aset yang dimiliki oleh perusahaan.

$$
D E R=\frac{\text { Total hutang }}{\text { Total Aset }}
$$

\section{HASIL DAN PEMBAHASAN \\ 1. Uji Statistik Deskriptif Variabel}

Tabel 4.1

Hasil Uji Statistik

Descriptive Statistics

\begin{tabular}{|l|r|r|r|r|r|}
\hline & $\mathrm{N}$ & Minimum & Maximum & Mean & Std. Deviation \\
\hline Leverage Perusahaan & 45 & .01 & 9.55 & .7584 & 1.47764 \\
Kebijakan Dividen & 45 & .00 & 324.82 & 16.4044 & 51.84620 \\
Ukuran Perusahaan & 45 & 22.66 & 30.60 & 28.2005 & 1.76265 \\
Investment Opportunity & 45 & -.60 & 243.25 & 9.0685 & 36.51219 \\
Set (IOS) & & & & & \\
Valid N (listwise) & 45 & & & & \\
\hline
\end{tabular}

Sumber: Hasil Olahan Data SPSS, 2018

Berdasarkan hasil analisis deskripsi statistik pada tabel 4.1 diatas dapat diketahui bahwa jumlah data yang diteliti pada penelitian ini sebanyak 45 data. Hasil dari uji statistik deskripsi di atas dapat diinterpretasikan sebagai berikut:

1. Leverage perusahaan yang diukur dengan DER (Debt to Equity Ratio) memiliki rata-rata (mean) sebesar 0.759 dengan tingkat ratarata penyimpangan (Standar Deviasi) sebesar 1.477. Hal ini menunjukkan bahwa pada data variabel DER memiliki sebaran data yang besar, karena standar deviasi lebih besar dari nilai mean-nya.

2. Kebijakan dividen yang diukur dengan DPR (Dividend Payout Ratio) memiliki rata-rata (mean) sebesar 16.404 dengan tingkat ratarata penyimpangan (Standar Deviasi) sebesar 51.846. Hal ini menunjukkan bahwa pada data variabel DER memiliki sebaran data yang besar, karena standar deviasi lebih besar dari nilai mean-nya.

3. Ukuran Perusahaan yang diukur dengan Size ( $L_{n}$ Total Aset) memiliki rata-rata (mean) sebesar 28.2 dengan tingkat rata-rata penyimpangan (Standar Deviasi) sebesar 1.763. Hail ini menunjukkan data yang besar, karena standar deviasi lebih besar dari nilai mean-nya

4. Investment Opportunity Set (IOS) perusahaan yang diukur dengan MVEBVE (Market to Book Value Of Equity) memiliki rata-rata (mean) sebesar 9.068 dengan tingkat rata-rata penyimpangan (Standar Deviasi) sebesar $36.512 \mathrm{Hal}$ ini menunjukkan bahwa pada 
data variabel DER memiliki sebaran data yang besar, karena standar deviasi lebih besar dari nilai mean-nya.

\section{Uji Asumsi Klasik}

a. Uji Normalitas

Tabel 4.2

Hasil Uji Normalitas

\begin{tabular}{|c|c|c|}
\hline & $\begin{array}{c}\text { Standardized } \\
\text { Residual }\end{array}$ & Keterangan \\
\hline Kolmogorov-Smirnov Z & 1,352 & Data terdistribusi \\
normal
\end{tabular}

Pada tabel diatas dengan uji One-Sample Kolmogorov-Smirnov Test hasil dari uji tersebut menunjukan asymp. sig standardized residual adalah 0,052 . Hal ini dapat disimpulkan bahwa nilai signifikannya lebih besar dari alpha 0.05 dengan demikian menunjukan data terdistribusi secara nornal.

\section{b. Uji Multikolineritas}

Tabel 4.3

Hasil Uji Multikolineritas

\begin{tabular}{|c|c|c|c|c|}
\hline No & Variabel & Tolerance & VIF & Keterangan \\
\hline 1 & $\begin{array}{c}\text { Kebijakan } \\
\text { Dividen (X1) }\end{array}$ & 0.995 & 1.005 & $\begin{array}{c}\text { Tidak terjadi } \\
\text { Multikolinearitas }\end{array}$ \\
\hline 2 & $\begin{array}{c}\text { Ukuran } \\
\text { Perusahaan (X2) }\end{array}$ & 0.995 & 1.005 & $\begin{array}{c}\text { Tidak terjadi } \\
\text { Multikolinearitas }\end{array}$ \\
\hline
\end{tabular}

Sumber: Hasil Olahan Data SPSS, 2018

Berdasarkan Tabel 4.3 di atas. dapat disimpulkan bahwa model regresi tersebut terbebas dari multikolinearitas. Hal ini terbukti dengan di nilai tolerance yang diperoleh untuk semua variabel independen besar dari 0,10 dan nilai VIF (Variance Inflation Factor) dibawah 10. Varibael Kebijakan Dividen (X1) menunjukkan bahwa nilai tolerance sebesar 0,995 > 0,10 dan nilai VIF sebesar 1,005 < 10 dan Ukuran Perusahaan (X2) menunjukkan bahwa nilai tolerance sebesar 0,995 > 0.10 dan nilai VIF sebesar $1,005<10$.

\section{c. Uji Heteroskedastisitas}

Tabel 4.4

Hasil Uji Heteroskedastisitas 


\begin{tabular}{|c|c|c|c|c|}
\hline No & Variabel & Alpha & Asymp.Sig & Keterangan \\
\hline 1 & $\begin{array}{c}\text { Kebijakan Dividen } \\
(\mathrm{X} 1)\end{array}$ & 0,05 & 1,000 & $\begin{array}{c}\text { Tidak terjadi } \\
\text { Heteroskedastisitas }\end{array}$ \\
\hline 2 & $\begin{array}{c}\text { Ukuran Perusahaan } \\
(\mathrm{X} 2)\end{array}$ & 0,05 & 1,000 & $\begin{array}{c}\text { Tidak terjadi } \\
\text { Heteroskedastisitas }\end{array}$ \\
\hline
\end{tabular}

Sumber: Hasil Olahan Data SPSS, 2018

Dari hasil uji heteroskedastisitas pada tabel $4.4 \mathrm{di}$ atas menunjukan bahwa nilai Asymp. Sig pada semua variabel bebas (independen) adalah 1,0. Hal ini menunjukan bahwa nilai Asymp. Sig lebih besar dari alpha 0,05 sehingga dapat disimpulkan bahwa semua variabel independen pada penilitian ini tidak terjadi heteroskedastisitas.

\section{Analisis Regresi Linear dengan Variabel Moderasi}

Tabel 4.5

Hasil Uji Analisis Regresi Linear Tahap I

\begin{tabular}{|c|c|c|c|c|c|}
\hline \multirow[b]{2}{*}{ Model } & \multicolumn{2}{|c|}{$\begin{array}{l}\text { Unstandardized } \\
\text { Coefficients }\end{array}$} & \multirow{2}{*}{$\begin{array}{c}\text { Standardized } \\
\text { Coefficients }\end{array}$} & \multirow[b]{2}{*}{$\mathrm{t}$} & \multirow[b]{2}{*}{ Sig. } \\
\hline & B & Std. Error & & & \\
\hline 1 (Constant) & 15.103 & 2.902 & & 5.202 & .000 \\
\hline $\begin{array}{l}\text { Kebijakan Dividen } \\
\text { (X1) }\end{array}$ & .000 & .003 & -.033 & -272 & .787 \\
\hline $\begin{array}{l}\text { Ukuran Perusahaan } \\
\text { (X2) }\end{array}$ & -.50 & .103 & -.606 & -4.941 & .000 \\
\hline
\end{tabular}

Sumber: Hasil Olahan Data SPSS, 2018

Berdasarkan hasil analisis regresi linear tahap I diperoleh persamaan sebagai berikut:

1. $Y=a+\beta_{1} X_{1}+\beta_{2} X_{2}+e$

2. $\mathrm{Y}=15,103+0,0 \mathrm{X}_{1}-0,5 \mathrm{X}_{2}+\mathrm{e}$

Persamaan regresi tahap 1 di atas dapat diartikan bahwa:

1. Nilai Konstanta yaitu 15,103 dengan parameter positif yang mana dapat disimpulkan bahwa nilai Leverage Perusahaan adalah sebesar 15,103 dengan asumsi variabel lain bernilai nol.

2. Nilai Koefisien regresi Kebijakan Dividen yaitu 0,0 yang mana dapat disimpulkan bahwa peningkatan satu-satuan Kebijakan Dividen tidak mengakibatkan kenaikan atau penurunan nilai koefisien Leverage Perusahaan.

3. Nilai Koefisien regresi Ukuran Perusahaan yaitu $-0,5$ dengan parameter negatif yang mana dapat disimpulkan bahwa setiap peningkatan satu-satuan Ukuran Perusahaan maka akan 
mengakibatkan penurunan nilai koefisien Leverage Perusahaan sebesar $-0,5$.

Tabel 4.6

Hasil Uji Analisis Regresi Linear Tahap I

\begin{tabular}{|l|r|r|r|r|r|}
\hline \multirow{2}{*}{ Model } & \multicolumn{2}{|c|}{$\begin{array}{c}\text { Unstandardized } \\
\text { Coefficients }\end{array}$} & $\begin{array}{r}\text { Standardized } \\
\text { Coefficients }\end{array}$ & & \\
\cline { 2 - 5 } & \multicolumn{1}{|c|}{$\mathrm{B}$} & Std. Error & \multicolumn{1}{|c|}{ Beta } & \multicolumn{1}{c|}{ Sig. } \\
\hline (Constant) & 15.299 & 2.975 & & 5.142 & .000 \\
Kebijakan Dividen & -.001 & .004 & -.049 & -.366 & .717 \\
Ukuran Perusahaan & -.516 & .106 & -.616 & -4.886 & .000 \\
Interaksi Investment & & & & & \\
Opportunity Set*Kebijakan & .000 & .000 & .048 & .348 & .730 \\
Dividen & & & & & \\
Interaksi Investment & & & & & \\
Opportunity Set*Ukuran & 8.230 & .000 & .059 & .463 & .646 \\
Perusahaan & & & & \\
\hline
\end{tabular}

Sumber: Hasil Olahan Data SPSS, 2018

$\mathrm{Y}=\mathrm{a}+\beta_{1} \mathrm{X}_{1}+\beta_{2} \mathrm{X}_{2}+\beta_{3} \mathrm{X}_{1} * \mathrm{Z}+\beta_{4} \mathrm{X}_{2} * \mathrm{Z}$

$\mathrm{Y}=15,299+0,001 \mathrm{X}_{1}-0,516 \mathrm{X}_{2}+0,0 \mathrm{X}_{1} * \mathrm{Z}+8,230 \mathrm{X}_{2} * \mathrm{Z}$

Persamaan regresi tahap 2 di atas dapat diartikan bahwa:

1. Nilai Konstanta yaitu 15,299 dengan parameter positif yang mana dapat disimpulkan bahwa nilai Leverage Perusahaan adalah sebesar 15,103 dengan asumsi variabel lain bernilai nol.

2. Nilai Koefisien regresi interaksi antara Kebijakan Dividen dengan Investment Opportunity Set yaitu 0,0 yang mana dapat disimpulkan bahwa peningkatan satu-satuan interaksi antara Kebijakan Dividen dengan Investment Opportunity Set tidak mengalami kenaikan atau penurunan nilai koefisien Leverage Perusahaan.

3. Nilai Koefisien regresi interaksi antara Ukuran Perusahaan dengan Investment Opportunity Set yaitu 0,0 yang mana dapat disimpulkan bahwa peningkatan satu-satuan interaksi antara Ukuran Perusahaan dengan Investment Opportunity Set tidak mengalami kenaikan atau penurunan nilai koefisien Leverage Perusahaan.

4. $U$

Tabel 4.7

Hasil Uji Statistik F

\begin{tabular}{|c|c|c|c|c|c|}
\hline Model & $\begin{array}{l}\text { Sum of } \\
\text { Squares }\end{array}$ & $\mathrm{df}$ & Mean Square & $\mathrm{F}$ & Sig. \\
\hline Regression & 35.680 & 2 & 17.840 & 12.407 & .000 \\
\hline
\end{tabular}

otesis

a. Uji F (Simultan) 
Dari tabel 4.7 diketahui besarnya $\mathrm{F}$ hitung yang diperoleh adalah sebesar 12,407 dengan nilai signifikansi 0,00. Dengan menggunakan tingkat $\alpha$ (Alfa) $=0,05$ atau 5\% maka disimpulkan bahwa nilai signifikansi lebih keci dari alpha $(0,00<0,05)$. Dengan demikian Kebijakan Dividen dan Ukuran Perusahaan secara simultan berpengaruh terhadap leverage Perusahaan.

b. Uji T (Parsial)

Tabel 4.8

Hasil Uji Statistik T

\begin{tabular}{|l|c|c|c|c|}
\hline \multirow{2}{*}{ Model } & \multicolumn{2}{|c|}{ Tahap 1 } & \multicolumn{2}{c|}{ Tahap 2 } \\
\cline { 2 - 5 } & $\mathrm{t}$ & Sig. & $\mathrm{t}$ & Sig. \\
\hline (Constanta) & 5.205 & .000 & 5.142 & .000 \\
\hline Kebijakan Dividen & -.272 & .787 & -.366 & .717 \\
\hline Ukuran Perusahaan & -4.941 & .000 & -4.886 & .000 \\
\hline $\begin{array}{l}\text { Interaksi Investment Opportunity } \\
\text { Set*Kebijakan Dividen }\end{array}$ & & & .343 & .730 \\
\hline $\begin{array}{l}\text { Interaksi Investment Opportunity } \\
\text { Set*Ukuran Perusahaan }\end{array}$ & & & .46 & .646 \\
\hline
\end{tabular}

Sumber: Hasil Olahan Data SPSS, 2018

Adapun hasil dari pengujian statistik t (uji t) pada penilitian ini adalah sebagai berikut :

1. Variabel Kebijakan Dividen $\left(\mathrm{X}_{1}\right)$ memiliki nilai t hitung sebesar 0,272 dengan nilai signifikan 0,717 yaitu kecil dari taraf signifikan $0,05(5 \%)$. Hal ini menunjukan bahwa variabel Kebijakan Dividen $\left(\mathrm{X}_{1}\right)$ berpengaruh negatif dan tidak signifikan terhadap Leverage Perusahaan (Y). Hasil uji t ini berarti menolak hipotesis $1\left(\mathrm{H}_{1}\right)$.

2. Variabel Ukuran Perusahaan $\left(\mathrm{X}_{2}\right)$ memiliki nilai t hitung sebesar 4.941 dengan nilai signifikan 0,000 yaitu kecil dari taraf signifikan $0,05(5 \%)$. Hal ini menunjukan bahwa variabel Ukuran Perusahaan (X2) berpengaruh positif dan signifikan terhadap variabel Leverage Perusahaan(Y). Hasil uji t ini berarti menerima hipotesis $2\left(\mathrm{H}_{2}\right)$.

3. Variabel moderasi dalam penelitian ini adalah Investment Opportunity Set $(Z)$ dengan memiliki nilai t hitung pada interkasi Investment Opportunity Set (Z) dengan Kebijakan Dividen (X1) sebesar 0,343 dengan nilai signifikan 0,730 yaitu besar dari taraf signifikan 0,05 (5\%). Hal ini menunjukan bahwa variabel Investment Opportunity Set $(Z)$ berpengaruh positif dan tidak signifikan terhadap hubungan antara Kebijakan Dividen (X1) dengan variabel Leverage Perusahaan (Y). Hasil uji t ini berarti menolak hipotesis $3\left(\mathrm{H}_{3}\right)$.

4. Variabel moderasi dalam penelitian ini adalah Investment Opportunity Set $(Z)$ dengan memiliki nilai t hitung pada interkasi Investment Opportunity Set $(Z)$ dengan Ukuran Perusahaan (X2) 
sebesar 0,463 dengan nilai signifikan 0,646 yaitu besar dari taraf signifikan 0,05 (5\%). Hal ini menunjukan bahwa variabel Investment Opportunity Set $(Z)$ berpengaruh positif dan tidak signifikan terhadap hubungan antara Ukuran Perusahaan (X2) dengan variabel Leverage Perusahaan (Y). Hasil uji t ini berarti menerima hipotesis $4\left(\mathrm{H}_{4}\right)$.

\section{Uji R-Square (Koefisien Determinasi)}

Tabel 4.8

Hasil Uji Statistik T

\begin{tabular}{|l|r|r|r|c|}
\hline Model & $\mathrm{R}$ & R Square & $\begin{array}{c}\text { Adjusted R } \\
\text { Square }\end{array}$ & $\begin{array}{c}\text { Std. Error of the } \\
\text { Estimate }\end{array}$ \\
\hline 1 & $.609^{\mathrm{a}}$ & .371 & .341 & 1.19912 \\
\hline
\end{tabular}

Sumber: Hasil Olahan Data SPSS, 2018

Berdasarkan hasil dari uji koefisien determinasi di atas dapat dilihat pada nilai Adjusted $\mathrm{R}$ Square sebesar 0,341. Hal ini menunjukan variabilitas variabel dependen dijelaskan oleh variabel independen sebesar 34,1\% atau dapat diartikan bahwa 34,1\% tingkat Leverage dipengaruhi oleh Kebijakan Dividen $\left(\mathrm{X}_{1}\right)$, dan Ukuran Perusahaan $\left(\mathrm{X}_{2}\right)$, sedangkan sisanya sebesar $65,9 \%$ dipengaruhi oleh variabel lain, yang tidak diteliti pada penelitian ini.

\section{Pembahasan}

Dari pengujian hipotesis yang telah dilakukan dengan melakukan pengujian terhadap persamaan regresi tentang pengaruh Kebijakan Dividen dan Ukuran Perusahaan terhadap Leverage, serta pengaruh Investment Opportunity Set dalam memoderasi pengaruh Kebijakan Dividen dan Ukuran Perusahaan terhadap Leverage Perusahaan. Maka hasil tersebut dapat diperoleh sebagai berikut :

\section{Pengaruh Kebijakan Dividen terhadap Leverage Perusahaan}

Hasil pengujian hipotesis yang telah dilakukan pada hipotesis 1 menunjukan bahwa variabel Kebijakan Dividen tidak berpengaruh terhadap Leverage Perusahaan, yang mana dapat diketahui nilai signifikansi yang diperoleh adalah 0,717 yaitu besar dari taraf signifikan $0,05(5 \%)$. Hal tersebut dapat disimpulkan bahwa Kebijakan Dividen berpengaruh negatif dan tidak signifikan terhadap Leverage Perusahaan, artinya keputusan mengenai apakah laba yang diperoleh perusahaan akan dibagikan kepada pemegang saham sebagai dividen atau diinvestasikan kembali tidak berdampak terhadap kebijakan hutang perusahaan, namun hal ini tergantung kepada pihak perusahaan dalam memutuskan kebijakan apa yang perlu diambil. Dengan demikian dapat dinyatakan bahwa hipotesis $1\left(\mathrm{H}_{1}\right)$ ditolak. 
Hasil penelitian ini sesuai dengan penelitian yang telah dilakukan oleh Djabid (2009) tentang Kebijakan Dividen dan Struktur Kepemilikan Modal terhadap Kebijakan Hutang pada perusahaan manufaktur yang terdaftar di Bursa Efek Indonesia dari tahun 2004 - 2008 yang menyatakan bahwa Kebijakan Dividen tidak berpengaruh terhadap Kebijakan Hutang. Hasil yang sama juga dilakukan oleh Wahidahwati (2002) dalam Yulius Kurnia Susanto (2011) tentang Kepemilikan Ssaham, Kebijakan Dividen, Karakteristik Perusahaan, Risiko Sistimatik, Set Peluang Investasi dan Kebijakan Hutang pada perusahaan manufaktur yang terdaftar di Bursa Efek Indonesia dari tahun 2005 - 2008 yang menyatakan bahwa Kebijakan Dividen berpengaruh negatif dan tidak signifikan terhadap Kebijakan Hutang.

\section{Pengaruh Ukuran Perusahaan terhadap Leverage Perusahaan}

Hasil pengujian hipotesis yang telah dilakukan pada hipotesis 2 menunjukan bahwa variabel Ukuran Perusahaan berpengaruh terhadap Leverage, yang mana dapat diketahui nilai signifikansi yang diperoleh 0,000 yaitu kecil dari taraf signifikan 0,05 (5\%). Hal tersebut dapat disimpulkan bahwa Ukuran Perusahaan berpengaruh positif dan signifikan terhadap Leverage Perusahaan, artinya dilihat dari seberapa besar ukuran perusahaan yang diukur dengan total aset yang dimiliki oleh perusahaan akan berdampak pada kemudahan perusahaan dalam memperoleh dana eksternal yaitu hutang. Dengan demikian dapat dinyatakan bahwa hipotesis $2\left(\mathrm{H}_{2}\right)$ diterima.

Hasil penelitian ini sesuai dengan penelitian yang telah dilakukan oleh Moh. Syadeli (2013) tentang Struktur Kepemilikan, Profitabilitas dan Ukuran Perusahaan Terhadap Kebijakan Hutang pada perusahaan manufaktu yang terdaftar di Bursa Efek Indonesia dari tahun 2008 - 2010 menemukan bahwa Ukuran Perusahaan berpengaruh signifikan terhadap Kebijakan Hutang. Hasil yang sama ditemukan oleh Nuraina (2012) tentang Pengaruh Kepemilikan Institusional dan Ukuran Perusahaan Terhadap Kebijakan Hutang dan Nilai Perusahaan pada perusahaan manufaktur yang terdaftar di Bursa Efek Indonesia dari tahun 2006 - 2008 yang menyatakan bahwa Ukuran Perusahaan berpengaruh signifikan terhadap Kebijakan Hutang.

\section{Pengaruh Kebijakan Dividen terhadap Leverage Perusahaan dengan Investment Opportunity Set (IOS) Sebagai Variabel Moderasi}

Hasil pengujian hipotesis yang telah dilakukan pada hipotesis 3 menunjukan bahwa variabel Investment Opportunity Set tidak berpengaruh terhadap hubungan Kebijakan Dividen dengan variabel Leverage Perusahaan yang mana dapat diketahui nilai signifikansi yang diperoleh dari interaksi Investment Opportunity Set dengan Kebijakan Dividen sebesar 0,730 yaitu besar dari taraf signifikan 0,05 (5\%). Hal tersebut dapat disimpulkan bahwa Investment Opportunity Set berpengaruh positif dan tidak signifikan terhadap pengaruh terhadap Kebijakan Dividen dengan variabel Leverage Perusahaan, artinya pilihan atau kesesmpatan 
investasi saat ini dan diharapkan akan menghasilkan keuntungan yang lebih banyak di masa yang akan datang tidak berdampak terhadap keputusan perusahaan dalam memutuskan untuk menggunakan dana ekternal yaitu hutang. Dengan demikian dapat dinyatakan bahwa hipotesis $3\left(\mathrm{H}_{3}\right)$ ditolak.

Hasil penelitian ini sesuai dengan hasil penelitian yang telah dilakukan oleh Kennedy, Fitrios, \& Fitri (2009) tentang Pengaruh Dividen, Aliran Kas Bebas, Ukuran Perusahaan, Profitabilitas dan Risiko terhadap Leveragae Perusahaan pada perusahaan manufaktur yang listing di Bursa Eek Indonesia selama tahun 2017 dengan Set Kesempatan Investasi (IOS) Sebagai Variabel Moderasi menemukan bahwa Investment Opportunity Set tidak mempengaruhi hubungan antara kebijakan dividen dengan Leverage perusahaan. Hasil yang sama ditemukan oleh Masruroh, Nursanti, \& Lisa (2011) tentang Analisis Pengaruh Moderasi Investment Opportunity Set dengan Kebijakan Dividen Serta Moderasi Investment Opportunity Set dengan Arus Kas Bebas Terhadap Tingkat Leverage Perusahaan pada perusahaan makanan dan minuman yang terdaftar di Bursa Efek Indonesia dari tahun 2003 - 2007 yang menyatakan bahwa Hasil moderated regression analysis menyimpulkan bahwa kebijakan dividen tidak mempengaruhi leverage perusahaan.

\section{Pengaruh Ukuran Perusahaan terhadap Leverage Perusahaan dengan Investment Opportunity Set (IOS) Sebagai Variabel Moderasi}

Hasil pengujian hipotesis yang telah dilakukan pada hipotesis 4 menunjukan bahwa variabel Investment Opportunity Set tidak berpengaruh terhadap hubungan antara Ukuran Perusahaan dengan variabel Leverage yang mana dapat diketahui nilai signifikansi yang diperoleh dar interaksi Investment Opportunity Set dengan Ukuran Perusahaan sebesar 0,646 yaitu kecil dari taraf signifikan 0,05 (5\%). Hal tersebut dapat disimpulkan bahwa Investment Opportunity Set berpengaruh positif dan tidak signifikan terhadap hubungan antara Ukuran Perusahaan dengan variabel Leverage Perusahaan, artinya kesempatan investasi perusahaan tidak berdampak begitu besar mengenai jaminan perusahaan dalam memperoleh sejumlah dana berbentuk hutang yang dilihat pada seberapa besar total aset yang dimliki oleh perusahaan. Dengan demikian dinyatakan bahwa hipotesis $4\left(\mathrm{H}_{4}\right)$ diterima.

Hasil penelitian ini sesuai dengan hasil penelitian yang telah dilakukan oleh Kennedy, Fitrios, \& Fitri (2009) tentang Pengaruh Dividen, Aliran Kas Bebas, Ukuran Perusahaan, Profitabilitas dan Risiko terhadap Leveragae Perusahaan dengan Set Kesempatan Investasi (IOS) Sebagai Variabel Moderasi pada perusahaan manufaktur yang listing di Bursa Eek Indonesia selama tahun 2017 dengan Set Kesempatan Investasi (IOS) Sebagai Variabel Moderasi menemukan bahwa Investment Opportunity Set tidak mempengaruhi hubungan antara kebijakan dividen dengan Leverage perusahaan. Hasil yang sama juga ditemukan oleh Rofniati (2007) tentang Analisis Moderasi Investment Opportunity Set (IOS) 
Terhadap Hubungan Antara Dividen, Aliran Kas Bebas, Ukuran Perusahaan dan Profitabilitas Dengan Tingkat Leverage Perusahaan pada perusahaan manufaktur yang terdaftar di Bursa Efek Indonesia pada tahun 2004 - 2006 bahwa IOS tidak mempengaruhi hubungan antara Ukuran Perusahaan dengan Leverage perusahaan.

\section{DAFTAR PUSTAKA}

Andriza, R., \& Yusra, I. (2019). Pengaruh kepemilikan manajerial dan kebijakan deviden terhadap kemakmuran Investor dan nilai perusahaan yang tercatat pada indeks LQ45. INA-Rxiv.

Arieska, M., \& Gunawan, B. (2009).Pengaruh Aliran Kas Bebas dan Keputusan Pendanaan Terhadap Nilai Pemegang Saham dengan Set Kesempatan Investasi dan Dividen Sebagai Variabel Moderasi.Akuntansi Dan Keuangan, 13(1), 13-23.

Aristantia, D., \& Putra, I. M. P. D. (2015). Investment Opportunity Set Dan Free Cash Flow Pada Tingkat Pembayaran Dividen Perusahaan Manufaktur. EJurnal Akuntansi Unud, 1, 220-234.

Astuti, A. P., \& Efni, Y. (2015). Pengaruh Kesempatan Investasi, Leverage Terhadap Kebijakan Deviden dan Nilai Perusahaan Pada Perusahaan Manufaktur yang Terdaftar di Bursa Efek Indonesia. Jurnal Tepak Manajemen Bisnis, VII(3), 343-356.

Danil, A., \& Yusra, I. (2019). Pengaruh kausal antara ukuran perusahaan, nilai buku dan likuiditas saham di Bursa Efek Indonesia. INA-Rxiv.

Erawati, L., \& Dewi, A. S. (2019). Peran Profitabilitas Sebagai Variabel Interverning Dan Pengaruh Struktur Modal Terhadap Nilai Perusahaan. INARxiv.

Febriana, E., Djumahir, \& Djawahir, A. H. (2013). Kepemilikan Saham Manajerial dan Profitabilitas Terhadap Nilai Perusahaan ( Studi pada Perusahaan Manufaktur yang Terdaftar di BEI Pada 2011-2013 ). Jurnal Ekonomi Bisnis.

Gusnita, E., \& Martha, L. (2019). Analisis Struktur Modal Dalam Memoderasi 
Pengaruh Kepemilikan Manajerial Dan Pertumbuhan Perusahaan Terhadap Nilai Perusahaan Di Indonesia. INA-Rxiv.

Hanafi, D., \& Yusra, I. (2019). Tangibility, liquidity, growth opportunity, dan leverage: studi pada perusahaan terdaftar di Bursa Efek Indonesia. INA-Rxiv, (2001).

Harahap, R. L., \& Sari, L. F. (2019). Analisis Nilai Perusahaan Berdasakan Profitabilitas, Ukuran Perusahaan, Dan Struktur Modal Di Indonesia. INARxiv.

Hemastuti, C. pami. (2014). Pengaruh Profitabilitas, Kebijakan Dividen, Kebijakan Hutang, Keputusan Investasi dan Kepemilikan Insider Terhadap Nilai Perusahaan. Jurnal Ilmu \& Riset Akuntansi, 3(4), 1-14.

Kennedy, Fitrios, R., \& Fitri, R. (2009). Pengaruh Dividen, Aliran Kas Bebas, Ukuran Perusahaan, Profitabilitas Dan Risiko Terhadap Leverage Perusahaan Dengan Set Kesempatan Investasi (IOS) Sebagai Variabel Moderating (Suatu Studi Empiris Terhadap Perusahaan Manufaktur Yang Listing di Bursa Efek. Kajian Akuntansi Dan Auditing, 4(1).

Larasati, E. (2011). Pengaruh Kepemilikan Manajerial , Kepemilikan Institusional dan Kebijakan Dividen terhadap Kebijakan Hutang Perusahaan. Ekonomi Bisnis, 16(2), 103-107.

Liputan6. (2017). Ekonom Sebut Daya Beli Masyarakat Turun, Ini Sebabnya. Retrieved from http://bisnis.liputan6.com/read/3040594/ekonom-sebut-dayabeli-masyarakat-turun-ini-sebabnya

Martha, L., Sogiroh, N. U., Magdalena, M., \& Susanti, F. (2018). Profitabilitas dan Kebijakan Dividen terhadap Nilai Perusahaan. Jurnal Benefita, 3(2), 227-238.

Masruroh, Nursanti, T. D., \& Lisa. (2011). Analisis Pengaruh Moderating Investment Opportunity Set Dengan Kebijakan Dividend Serta Moderating Investment Opportunity Set Dengan Arus Kas Bebas Terhadap Tingkat Leverage Perusahaan Makanan dan Minuman Yang Terdaftar di BEI Periode 2003-2007. T He WINNERS, 12(2), 121-141.

Nabela, Y. (2012). Pengaruh Kepemilikan Institusional, Kebijakan Dividen dan Profitabilitas Terhadap Kebijakan Hutang Pada Perusahaan Properti dan Real Estate di Bursa Efek Indonesia. Manajemen, 1(1), 1-8. 
Novari, P. M., \& Lestari, P. V. (2016). Pengaruh Ukuran Perusahaan, Leverage, dan Profitabilitas Terhadap Nilai Perusahaan Pada Sektor Properti dan Real Estate. E-Jurnal Manajemen Unud, 5(9), 5671-5694.

Nuraina, E. (2012). Pengaruh Kepemilikan Institusional dan Ukuran Perusahaan Terhadap Kebijakan Hutang Dan Nilai Perusahaan (Studi Pada Perusahaan Manufaktur yang Terdaftar di BEI).Bisnis Dan Ekonomi, 19(2), 110-125.

Purnama, S., \& Mayliza, R. (2019). Nilai Perusahaan Di Lihat Dari Aspek Profitabilitas, Ukuran Perusahaan Dengan Struktur Modal Sebagai Variabel Intervening. INA-Rxiv.

Purnami, K. D. A., \& Artini, L. G. S. (2016). Pengaruh Investment Opportunity Set, Total Asset Turn Over dan Sales Growth Terhadap Kebijakan Dividen. E-Jurnal Manajemen Unud, 5(2), 1309-1337.

Putra, A. D., \& Yusra, I. (2019). Peran profitabilitas dalam memoderasi pengaruh free cash flow terhadap kebijakan dividen di Indonesia. INA-Rxiv.

Qusibah, V. L., \& Yusra, I. (2019). Profitabilitas , dan Ukuran Perusahaan Sebagai Faktor Penentu Leverage Perusahaan Di Indonesia. Jurnal Pundi, 03(01), 13-26. https://doi.org/10.31575/jp.v3i1.125

Rofniati, (2007), Analisis Moderasi Set Kesempatan Investasi (IOS) Terhadap Hubungan Antara Dividen, Aliran Kas Bebas, Ukuran Perusahaan Dan Profitabilitas Dengan Tingkat Leverage Perusahaan. Skripsi Fakultas Ekonomi UNRI.

Suharli, M. (2007). Pengaruh Profitability dan Investment Opportunity Set Terhadap Kebijakan Dividen Tunai dengan Likuiditas Sebagai Variabel Penguat ( Studi pada Perusahaan yang Terdaftar di Bursa Efek Jakarta Periode 2002-2003 ). Akuntansi Dan Keuangan, 9(1), 9-17.

Susanto, Y. K. (2011). Kepemilikan Saham, Kebijakan Dividen, Karakteristik Perusahaan, Risiko Sistimatik, Set Peluang Investasi dan Kebijakan Hutang. Bisnis Dan Akuntansi, 13(3), 195-210.

Suwardika, I. N. A., \& Mustanda, I. K. (2017). Pengaruh Leverage, Ukuran Perusahaan, Pertumbuhan Perusahaan, dan Profitabilitas Terhadap Nilai Perusahaan Pada Perusahaan Properti. E-Jurnal Manajemen, 6(3), 12481277. 
Syadeli, M. (2013). Struktur Kepemilikan, Profitabilitas dan Ukuran Perusahaan Terhadap Kebijakan Hutang Perusahaan Pemanufakturan di Bursa Efek Indonesia. Manajemen Dan Akuntansi, 2(2), 79-94.

Wahyuni, I., \& Mayliza, R. (2019). Peran Kebijakan Deviden Dalam Memediasi Pengaruh Profitabilitas Terhadap Nilai Perusahaan. INA-Rxiv.

Yusra, I., Hadya, R., Begawati, N., \& Istiqomah, L. (2019). Panel data model estimation: the effect of managerial ownership, capital structure, and company size on corporate value Panel data model estimation : the effect of managerial ownership, capital structure, and company size on corporate value. Journal of Physics: Conference Series, 1175, 1-6. https://doi.org/10.1088/1742-6596/1175/1/012285

Yusra, I., Hadya, R., \& Fatmasari, R. (2019). The Effect of Retained Earnings on Dividend Policy from the Perspective of Life Cycle. Advances in Social Science, Education and Humanities Research, 203(Iclick 2018), 216-220.

Yusuf, D., \& Yusra, I. (2019). Faktor-faktor yang mempengaruhi struktur modal perusahaan. INA-Rxiv. 